\title{
PENGUATAN PEMAHAMAN KEBERAGAMAN SUKU, AGAMA, RAS DAN ANTAR GOLONGAN SISWA MELALUI PROBLEM BASED LEARNING
}

\author{
Enok Wijenar \\ Sekolah Menengah Pertama Negeri 4 Depok Jawa Barat, Jalan Merdeka Raya Depok II Tengah, Mekar Jaya, \\ Kec. Sukmajaya, Kota Depok, Jawa Barat 16411, enokwj@gmail.com
}

Diterima 28 Februari 2020, disetujui 15 April 2020, diterbitkan 30 April 2020

Pengutipan: Wijenar, E. (2020). Penguatan Pemahaman Keragaman Suku, Agama, Ras, dan Antar Golongan Siswa Melalui Problem Based learning.Gema Wiralodra, Vol 11, No 1, Hal 35-44, April 2020

\begin{abstract}
ABSTRAK
Keberagaman suku, agama, ras dan antar golongan menjadi pilar keutuhan bangsa dalam bernegara. Peserta didik sebagai wakil dari penerus bangsa diharapkan dapat memahami makna dari keberagaman suku, agama, ras dan antar golongan dan mampu mengaplikasikannya dalam kehidupan sehari-hari melalui pengenalan budaya yang diusung dari keberagaman tersebut. Oleh karena itu, penelitian ini bertujuan untuk meningkatkan pemahaman keberagamaan suku, agama, ras dan antar golongan melalui problem based learning. Desain penelitian yang digunakan yakni classroom action research. Sedangkan tindakan yang diberikan berupa problem based learning. Partisipan yang terlibat dalam penelitian ini berjumlah 36 siswa kelas VII-A di salah satu Sekolah Menengah Pertama Negeri yang ada di Depok, Jawa Barat pada Tahun Pelajaran 2019/2020 semester ganjil. Hasil penelitian menunjukkan ada peningkatan pemahaman siswa tentang makna budaya daerah sebagai pengukuh keberagaman suku, agama, ras dan antar golongan dalam bingkai bhineka tunggal ika di kehidupan sehari-hari.
\end{abstract}

Kata Kunci: Pemahaman siswa, keberagaman suku, agama, ras dan antar golongan, problem based learning, Sekolah Menengah Pertama

ABSTRACT

Ethnic, religious, racial and inter-group diversity is a pillar of national integrity in the state. Students as representatives of the nation's successors are expected to be able to understand the meaning of the diversity of tribes, religions, races and between groups and be able to apply it in everyday life through the introduction of culture that is carried out from such diversity. Therefore, this study aims to improve understanding of ethnic, religious, racial and intergroup diversity through problem based learning. The research design used is classroom action research. While the actions given are problem based learning. Participants involved in this study were 36 students of class VII-A in one of the State Junior High Schools in Depok, West Java in the 2019/2020 Academic Year odd semester. The results showed there was an increase in students' understanding of the meaning of regional culture as an affirmation of ethnic, religious, racial and intergroup diversity within a single diversity frame in everyday life.

Keywords: Student understanding, ethnic diversity, religion, race and class, problem based learning, junior high school

\section{PENDAHULUAN}

Indonesia merupakan negara multikultur terbesar di dunia yang dapat terlihat dari kondisi sosiokultural maupun geografis yang begitu kompleks, beragam, dan luas (Wahyuningsih, Suryono, Al Rasyid, 2018). Oleh karena itu kita harus mendorong lahirnya generasi cerdas yang berwatak dan berperadaban pada tanah air serta inklusif menghadapi

Diterbitkan oleh:

Universitas Wiralodra

Jln. Ir. H. Juanda Km 3 Indramayu, Jawa Barat 
perubahan zaman. Salah satu cara untuk mendorong lahirnya generasi cerdas yakni melalui pendidikan. Pendidikan memegang peranan yang sangat penting untuk meningkatkan sumber daya manusia yang berkualitas, kehidupan yang cerdas, damai, terbuka, dan demokratis (Yuniwati \& Siasah, 2016). Hal itu karena, pendidikan merupakan jembatan antara terbentuknya penguatan pemahaman keberagaman suku, agama, ras dan antar golongan. Sekolah sebagai alat pendidikan harus mampu mendesain proses pembelajaran, mempersiapkan kurikulum dan desain evaluasi, serta mempersiapkan guru yang memiliki persepsi, sikap dan perilaku multikultural, sehingga menjadi bagian yang memberikan kontribusi positif terhadap pembinaan sikap multikultural para siswanya (Rosyada, 2014).

Penelitian-penelitian dalam bidang pendidikan yang mencoba untuk membentuk pemahaman keberagaman suku, agama, ras dan antar golongan melalui pendidikan, khususnya pada proses pembelajaran di kelas. Misalkan penelitian Ukiyatiningsih (2019) hasil penelitian ini dapat disimpulkan bahwa dengan penerapan metode problem based learning (PBL) dapat meningkatkan prestasi belajar PPKn materi keberagaman suku, ras, dan antar golongan pada siswa kelas VII A SMP Negeri 6 Sukoharjo Semester II Tahun Pelajaran 2018/2019. Yuniwati \& Siasah (2016) Hasil penelitian menunjukan bahwa penerapan model Problem based learning dapat meningkatkan kualitas pembelajaran PPKn pada aspek proses pembelajaran dan hasil belajar yang komprehensif (kognitif, afektif, dan psikomotorik). Afifah (2017) Pembelajaran berbasis Multikultur dan budaya adalah pembelajaran dengan memberdayakan siswa untuk mengembangkan rasa hormat kepada orang yang berbeda budaya, memberi kesempatan untuk bekerja bersama dengan orang atau kelompok orang yang berbeda etnis, ras, agama maupun bahasa secara langsung.

Keragaman suku, agama, ras dan antar golongan dalam bingkai bhineka tunggal ika perlu dikenalkan melalui budaya daerah (Lestari, 2015). Pluralitas dan heterogenitas yang tercermin pada masyarakat Indonesia diikat dalam prinsip persatuan dan kesatuan bangsa yang kita kenal dengan semboyan "Bhinneka Tunggal Ika”,yang mengandung makna meskipun Indonesia (Lestari, 2015). Ada banyak cara untuk melakukan penguatan nilai-nilai Keragaman suku, agama, ras dan antar golongan dalam bingkai bhineka tunggal ika. Salah satu cara yakni melalui aktualisasi sosialisasi nilai-nilai pancasila diharapkan menjadi lebih membumi dimasyarakat Indonesia dengan melibatkan semua pihak untuk aktif berpartisipasi membumikan nilai-nilai pancasila ke semua aspek kehidupan, di tiga

Diterbitkan oleh: 
ranah pendidikan informal, formal dan non formal guna membentuk karakter yang baik pada generasi bangsa, sehingga akseptabilitas dan kredibilitas pancasila dapat terjaga dalam meningkatkan kesadaran dan tanggung jawab generasi bangsa terhadap masa depan yang berkualitas, cerdas, dan berkarakter (Alaby, 2019).

Selain itu, cara lain yakni melalui proses pembelajaran dengan menggunakan problem based learning. Upaya ini dilakukan dengan cara mengenalkan makanan daerah dan riwayat di dalamnya sebagai bentuk penyampaian bahasa yang tumbuh untuk pembelajaran layakknya bazar. Dimana siswa memanfaatkan teknologi untuk menelusuri sejarah dan ikut membuat atau berburu makanan yang masih ada menjual makanan khas seperti di daerah Depok Lama (masih termasuk Pancoran Mas), juga bertanya pada tetua di sekitar yang mengenal Depok dengan baik.

Berdasarkan hal itu, penelitian ini bertujuan untuk meningkatakan pemahaman siswa tentang keberagaman suku, agama, ras dan antar golongan siswa melalui problem based learning.

\section{METODE PENELITIAN}

Penelitian ini dilakukan di SMP Negeri 4 Depok pada siswa kelas VII-A yang berjumlah 36 siswa di semester ganjil. Terdiri dari 18 siswa laki-laki dan 18 siswa perempuan. Adapun metode yang diterapkan adalah jenis penelitian tindakan kelas. Penelitian Tindakan Kelas menurut Mills dalam Hopkins (2011:88) adalah penelitian tindakan untuk memperoleh pemahaman, mengembangkan praktik reflektif, memengaruhi perubahan-perubahan positif dalam lingkungan sekolah dan praktik-praktik pendidikan secara umum, dan untuk meningkatkan hasil-hasil pembelajaran siswa. Prosedur yang diterapkan adalah siswa dihadapkan pada persoalan yang sudah disinggung dalam pendahuluan sebagai sebuah bentuk pembelajaran problem based learning yakni siswa berhadapan dengan makanan minuman luar dan mengakrabinya. Hal ini adalah masalah yang harus dipecahkan karena berpotensi merusak keberagaman suku, agama, ras dan antar golongan dalam bingkai bhineka tunggal ika. Berikutnya siswa menelusuri makanan dan latar historinya dari internet dan bertanya pada orang tua atau yang dituakan di sekitar yang sangat paham dengan Depok. Selanjutnya makanan dan riwayat sejarahnya juga kandungannya disajikan di kelas seperti bazar yang dipresentasikan. Dan sebelumnya

Diterbitkan oleh: 
siswa pernah juga mengadopsi dari kegiatan sekolah bertajuk 'Kampoeng Pasmer'. 'Kampoeng Pasmer" adalah hajat sekolah mengenalkan budaya di sekitar kota Depok mencakup pakaian, makanan, distrik, profesi dan lanskap setiap kecamatan yang mendukung distrik kota Depok sejak dahulu sampai sekarang sehingga siswa memiliki data based apakah yang ada dalam keberagaman tersebut yang termaktub dalam materi PKn semester ganjil.

Selanjutnya diambil data tes tertulis uraian singkat di pertemuan 3 pada dua siklus yang berlangsung, data tes awal sebagai acuan untuk mengaplikasikan model pembelajaran ini berhasil atau tidak dalam menelisik kepahaman akan keberagaman suku, agama, ras dan antar golongan dalam bingkai bhineka tunggal ika, data lembar observasi dan kuesioner. Adapun data penelitiaan dianalisis secara deskriptif yang dihitung menggunakan rumus cara menghitung skor setiap aspek dengan rumus menurut Arikunto Suharsimi (2003:57):

$$
P=\frac{f}{n} x 100 \%
$$

Keterangan :

$\mathrm{P}=$ Persentase

$\mathrm{f}=$ Fekuensi yang ada pada katagori tertentu

$\mathrm{n}=$ Jumlah total atau keseluruhan jumlah subjek

Selanjutnya dibuatkan penskoran seperti pada tabel berikut:

Tabel 1 Kriteria Penskoran Lembar Observasi Siswa

\begin{tabular}{clc}
\hline Huruf & \multicolumn{1}{c}{ Kriteria } & $\begin{array}{l}\text { Persenta } \\
\text { se }\end{array}$ \\
\hline A & Sangat Baik & $81 \%-100 \%$ \\
\hline B & Baik & $61 \%-80 \%$ \\
\hline C & Cukup & $41 \%-60 \%$ \\
\hline D & Kurang & $21 \%-40 \%$ \\
\hline E & Kurang sekali & $0 \%-20 \%$ \\
\hline
\end{tabular}

(Nurgiyantoro, 2001)

Indikator keberhasilan bahwa siswa telah menguat kepahamannya terhadap materi keberagaman suku, agama, ras dan antar golongan dalam bingkai bhineka tunggal ika yakni melalui pengaplikasian model pembelajaran ini dikatakan berhasil adalah dengan penghitungan skor sebagai berikut :

$$
\mathrm{NA}=\frac{\text { Skor perolehan }}{\text { Skor maksimum }} \mathrm{X} 100 \%
$$


KKM yang ditentukan yakni 70 untuk KKM sekolah. Oleh karenanya penerapan model pembelajaran problem based learning dikatakan berhasil jika persentase keaktifan siswa lebih besar atau sama dengan $70 \%$, dikatakan tidak berhasil jika persentase keaktifan kurang dari 70\%, demikian juga dengan guru dikatakan berhasil bila skor perolehan mencapai lebih besar atau sama dengan $70 \%$.

\section{TEMUAN PENELITIAN DAN PEMBAHASAN}

Sebelum mengikuti proses pembelajaran dengan menggunakan model pembelajaran problem based learning pada kompetensi dasar keberagaman suku, agama, ras dan antar golongan dalam bingkai bhineka tunggal ika diberikan tes uraian singkat sebanyak 5 soal dan diperoleh hasil sebagai berikut :

Tabel 2 Hasil Pre Test Siklus I Pertemuan 1

\begin{tabular}{rrrrr}
\hline No. & \multicolumn{1}{c}{$\begin{array}{c}\text { Nilai } \\
\text { rata-rata }\end{array}$} & $\begin{array}{c}\text { Daya Serap } \\
(\boldsymbol{\%})\end{array}$ & KKM & $\begin{array}{c}\text { Ketuntasan } \\
(\boldsymbol{\%})\end{array}$ \\
\hline 1 & 60,22 & 55,82 & 70 & 61,11 \\
\hline
\end{tabular}

Melihat hasil tindakan pada pertemuan 1 ini siswa masih belum menunjukkan penguatan keberagaman suku, agama, ras dan antar golongan dalam bingkai bhineka tunggal ika yang berarti dari pembelajarannya ketuntasan masih di bawah KKM yakni hanya berkisar 22 orang dengan persentase $61,11 \%$. Dapat kita lihat dari pembacaan grafik di bawah ini masih belum memuaskan karena masih di bawah KKM yang diharapkan yakni 70: 


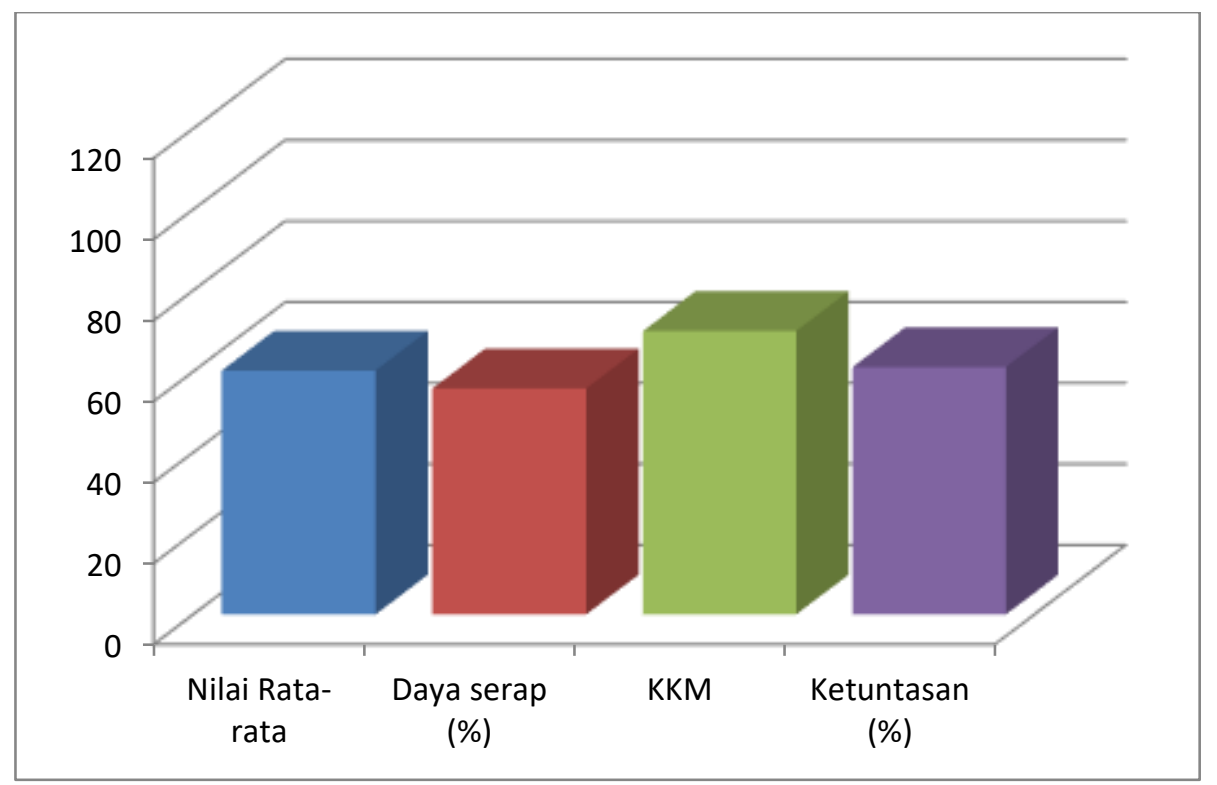

Gambar 1. Grafik Pencapaian Pre Test Siklus I

Setelah mengikuti proses pembelajaran dengan menggunakan model pembelajaran problem based learning pada kompetensi dasar keberagaman suku, agama, ras dan antar golongan dalam bingkai bhineka tunggal ika diberikan tes uraian singkat sebanyak 10 soal dan diperoleh hasil sebagai berikut:

Tabel 3 Hasil Post Test SiklusII Pertemuan 3

\begin{tabular}{rrrrr}
\hline \multirow{2}{*}{ No. } & \multicolumn{1}{l}{$\begin{array}{l}\text { Nilai } \\
\text { rata-rata }\end{array}$} & Daya Serap & \multicolumn{1}{c}{ KKM } & \multicolumn{1}{c}{ Ketuntasan } \\
\hline 1 & 81,13 & 81,13 & 70 & 83,33 \\
\hline
\end{tabular}

Di akhir dari penelitian tindakan yakni pertemuan 3 siklus II sudah tampak peningkatan hasil belajar yang cukup signifikan dari siswa yakni $81,13 \%$ dan mengalami kenaikan persentase ketuntasan sebesar 83,33\%. Artinya ada sekitar 30 siswa yang sudah tuntas belajarnya dalam kelas penguatan keberagaman suku, agama, ras dan antar golongan dalam bingkai bhineka tunggal ika. Hal ini berimplikasi bahwa penerapan model pembelajaran problem based learning cukup berhasil menaikan hasil belajar siswa kelas VII-A pada kompetensi dasar keberagaman suku, agama, ras dan antar golongan dalam bingkai bhineka tunggal ika semakin kuat dikukuhkan oleh siswa kelas VII-A di SMP Negeri 4 Depok. Bisa dilihat pada grafik berikut : 


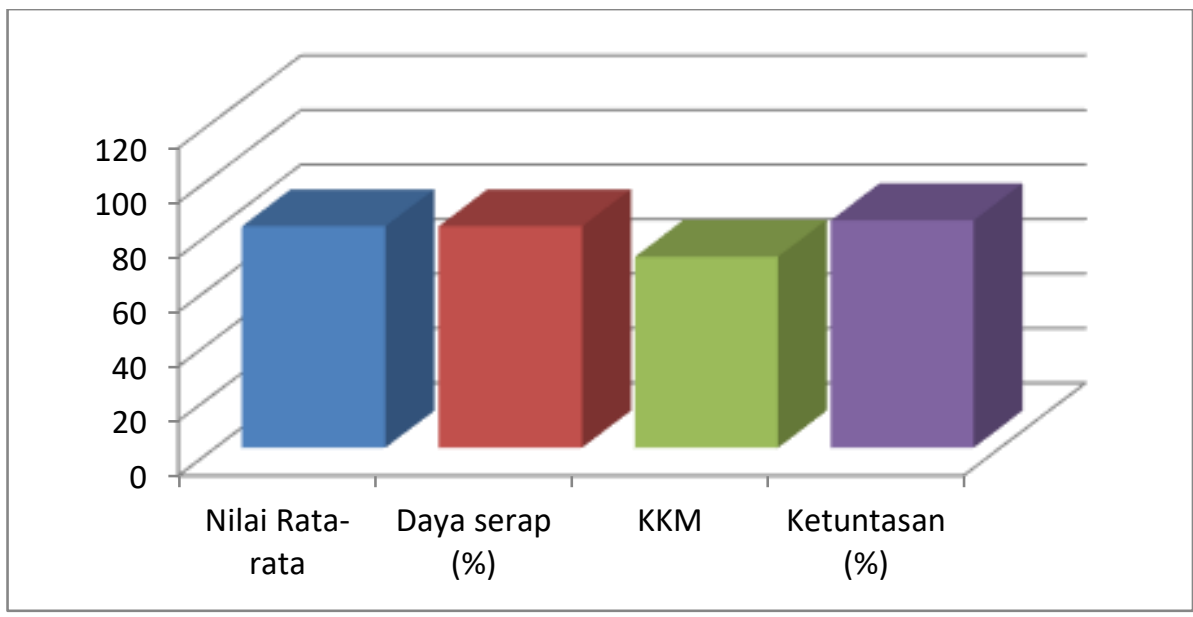

Gambar 2. Grafik Pencapaian Post Test SiklusII Pertemuan 3

Hasil penelitian non tes dari model pembelajaran poblem based learning diperoleh sebagai berikut:

Tabel 4 Kerja Tim Siklus II Pertemuan 3

\begin{tabular}{|c|c|c|c|}
\hline No. & Komponen Yang Diamati & Jumlah & Persentase \\
\hline 1 & Pengenalan Histori Budaya & 30 & $83,33 \%$ \\
\hline 2 & Antusias keikut sertaan & 29 & $80,56 \%$ \\
\hline 3 & Kerjasama & 32 & $88,89 \%$ \\
\hline 4 & Kemandirian & 29 & $80,56 \%$ \\
\hline 5 & $\begin{array}{lll}\text { Keragaman } & \text { Budaya } & \text { yang } \\
\text { Ditampilkan } & & \end{array}$ & 31 & $86,11 \%$ \\
\hline
\end{tabular}

Pada akhir dari siklus II, pada penelitian non tes tampak penguatan keberagaman suku, agama, ras dan antar golongan dalam bingkai bhineka tunggal ika melalui model pembelajaran problem based learning mencapai peningkatan yang sangat baik yakni sebesar $83,89 \%$. Siswa mengalami aktivitas pemelajaran yang saling mendukung terjadi kolaborasi di kelas dengan rekan sejawat dalam penguatan keberagaman suku, agama, ras dan antar golongan dalam bingkai bhineka tunggal ika sehingga pencapaian keberhasilan belajar sangat baik terlihat.

Siswa terinheren pengetahuannya tentang keberagaman suku, agama, ras dan antar golongan dalam bingkai bhineka tunggal ika melalui pengenalan budaya Depok. Materi dibawakan melalui pembelajaran bazar makanan minuman khas Depok di kelas serta menampilkan racikan bahan dari makanan minuman, latar historis dari budaya baik bahasa, 
sejarah geografis kecamatan yang mendukung kota Depok. Dari kegiatan ini terjadi apa yang menjadi ciri dari pembelajaran kurikulum 2013 yakni mengintegrasikan 4C dan HOTS dalam pemelajaran. HOTS tertampil dari pencarian informasi mengenai budaya Depok dan wawancara pada tetua di Depok serta penelusuran melalui kajian pustaka, sedangakan 4C dengan sendirinya terbangun transfer pengetahuan karena dipresentasikan serta terkolaborasi. Berpikir kritis ada pada pembandingan dengan budaya yang mereka kenal sehari-hari di sekitar mereka tumbuh dan beradaptasi. Ada pemahaman bahwa semisal pizza adalah bukan budaya kuliner bangsa ini namun diakulturasi dengan pizza berisi oncom yang merupakan makanan asli tanah pasundan yang turut membentuk Depok sebagai suatu kota. Siswa kreatif menyajikan 'presentasi' materi dengan inovasi yang mengakulturasi tanpa menghilangkan keragaman yang menjadi akar tanah berpijak yakni Depok. Kesemua ini diperoleh melalui observasi langsung, kuesioner yang diisi siswa dan diaplikasikan di kelas pembelajaran.

Hal ini juga dapat dilihat dari grafik di bawah ini keaktifan siswa sangat baik dan menggembirakan baik bagi siswa sendiri juga guru:

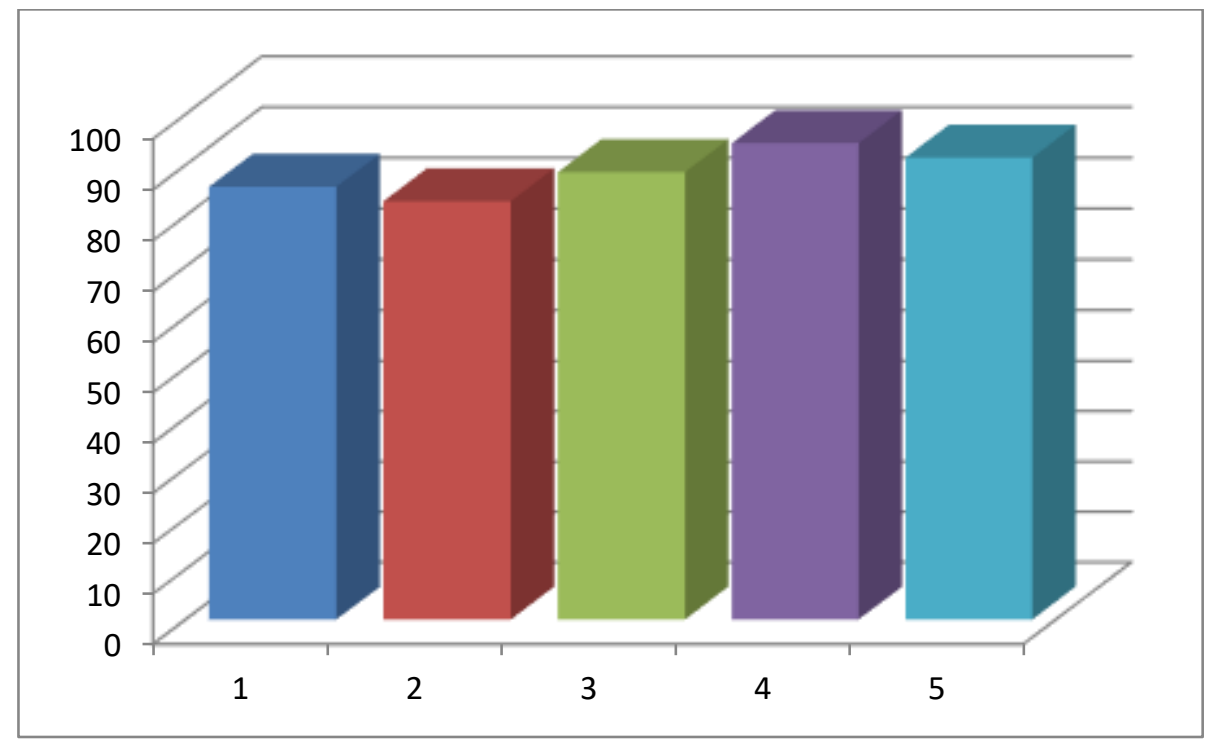

Gambar 3.Grafik Kerjasam Tim siklus II pertemuan 3

\section{KESIMPULAN}

Berdasarkan uraian hasil analisis penelitiaan baik dari tes maupun non tes beberapa simpulan yang dapat ditarik adalah: Pertama, adanya penguatan keberagaman suku, agama, ras dan antar golongan dalam bingkai bhineka tunggal ika baik melalui tes maupun non tes, 
yakni adanya peningkatan penguatan keberagaman suku, agama, ras dan antar golongan dalam bingkai bhineka tunggal ika siswa sebesar $81,13 \%$ dalam hasil tes serta ketuntasan $83,33 \%$, dikatagorikan hasilnya sangat baik. Artinya 30 siswa tuntas serta mampu menguasai keberagaman suku, agama, ras dan antar golongan dalam bingkai bhineka tunggal ika dan memahaminya sebagai bentuk penguatan karakter cinta tanah air dan aktivitas penguasaan pembelajaran sebagai bentuk penilaian non tes dicapai sebesar 83,89\%. Hal ini berkatagori sangat baik. Artinya materi yang dibawakan dengan bazar langsung makanan minuman khas Depok dan dipresentasikan ke depan kelas sangat baik menguatkan dasar dari keberagaman suku, agama, ras dan antar golongan dalam bingkai bhineka tunggal ika yakni daerah Depok sebagai wakil kecil dari Indonesia yang besar. Rasa nasionalis pun terbangun dengan sendirinya karena pembelajaran terintegrasi dimodelkan oleh guru.

Kedua, melalui model pembelajaran problem based learning dapat menstimulus siswa untuk memamahmi arti dari keberagaman suku, agama, ras dan antar golongan dalam bingkai bhineka tunggal ika sehingga menjadi menguat sebagai sebuah karakter cinta tanah air yang beragam dan majemuk. Siswa terbangun rasa kepemilikan terhadap tanahnya berpijak karena mereka tumbuh dalam masyarakat urban yang kental yang tak mengenal tanah asal. Siswa arif memilah bagian dari budayanya sendiri dan budaya asing.

Keitga, melalui pembelajaran problem based learning siswa berlatih menyelesaikan masalah yang dihadapi bangsanya yakni derasnya arus globalisasi yang dapat menggerus budaya lokal hal ini merupakan ciri bekerjanya cara berpikir HOTS. HOTS yang diperkenalkan adalah bagaimana siswa dihadapkan dengan kenyataan depan mata bahwa makanan minuman lokal yang meminggir akan menurunkan ketahanan berbangsa atau dengan kata lain budaya lokal yang diwakilkan dari makanan minuman daerah Depok adalah bagian kecil bangsa Indonesia. Bagian kecil ini turut menjadi kekayaan bangsa yang harus dijaga keutuhannya dan dilestarikan. Karena bangsa Indonesia dibentuk dari keberagaman suku, agama, ras dan antar golongan dalam bingkai bhineka tunggal ika, oleh karenanya di tangan siswa SMP Negeri 4 Depok sebagai salah satu wakil generasi mileniallah penjagaan keutuhan bernegara dan berbangsa itu berada. 


\section{DAFTAR PUSTAKA}

Afifah, N. (2017). Implementasi Pembelajaran Berbasis Multikultur dan Budaya di SD/MI. Ar-Riayah: Jurnal Pendidikan Dasar, Vol.1 No. 1, 2017

Alaby, A.M. (2019). Membumikan Nilai Pancasila pada Generasi Bangsa. Gema Wiralodra, Vol 10, No 2, Hal 179-189-61, Oktober 2019

Arikunto, Suharsimi. (2003). Prosedur Penelitian, Suatu Praktek. Jakarta: Bina Aksara.

Hopkins, D. (2011).Penelitian Tindakan Kelas.Yogyakarta:Pustaka Pelajar

Lestari, G. (2015). Bhinnekha Tunggal Ika: Khasanah Multikultural Indonesia Di Tengah Kehidupan Sara. Jurnal Pendidikan Pancasila dan Kewarganegaraan, Vol 28, No 1, Pebruari 2015

Nurgiyantoro, B. (2001). Penilaian dalan Pengajaran Bahasa dan Sastra. Yoggyakarta: BPFE

Rosyada, D.(2014). Pendidikan multikultural di Indonesia sebuah pandangan konsepsional. Sosio Didaktika: Vol. 1, No. 1 Mei 2014

Ukiyatiningsih. (2019). Upaya meningkatkan prestasi belajar ppkn materi keberagaman suku, ras, dan antar golongan melalui metode problem based learning (PBL). Journal Education and Economics, Vol 2, No 2, (2019)

Wahyuningsih, I, Suryono, H \& Al Rasyid, M. (2018). Hubungan Kemampuan Siswa Dalam Mengidentifikasi Keberagaman Suku, Agama, Ras, dan Antargolongan Dalam Bingkai Bhinneka Tunggal Ika Dengan Sikap Menghargai Keberagaman Suku, Agama, Ras, Dan Antargolongan (Studi Siswa Kelas Vii SMP Negeri 4 Surakarta). PKn Progresif: Jurnal Pemikiran dan Penelitian kewarganegaraan, Vol. 13 No. 2 Desember 2018

Yuniwati \& Siasah, M. (2016). Peningkatan Kualitas Pembelajaran Ppkn Melalui Penerapan Problem Based Learning di SMP. Harmoni Sosial: Jurnal Pendidikan IPS. Vol 3, No 2, September 2016 